\title{
WEED INTERFERENCE IN CARROT YIELD IN TWO LOCALIZED IRRIGATION SYSTEMS $^{1}$
}

\author{
LAÍS TEREZA RÊGO TORQUATO REGINALDO ${ }^{2}$, HAMURÁBI ANIZIO LINS $^{2 *}$, MATHEUS DE FREITAS SOUSA $^{2}$, \\ TALIANE MARIA DA SILVA TEÓFILO ${ }^{2}$, VANDER MENDONÇA ${ }^{2}$, DANIEL VALADÃO SILVA $^{2}$
}

\begin{abstract}
Weed interference is one of the factors that reduces carrot yield considerably. The aim of this study was to determine the periods of weed interference in carrots cultivated under two localized irrigation systems. The experiment used a completely randomized block design, with three replications, using the split plot scheme. The plots consisted of two irrigation systems (drip and micro sprinkler) and the subplots corresponded to the duration of coexistence of the crop with weeds, comprising periods of control (weed-free) or coexistence (with weeds) $(0,10,20,30,40,50$, and 120 days after emergence (DAE) of the crop). Considering a yield loss of $2.5 \%, 5 \%$, and $10 \%$ in marketable carrots, the beginning and end of the critical period of weed control (CPWC) was determined by adjusting a sigmoid model to the relative production data. The presence of the weed community throughout the crop cycle resulted in yield losses of up to $98 \%$. The CPWP varied for the irrigation systems used. Carrot cultivation with and without competition, under the micro sprinkler irrigation system showed a higher yield than with the drip system. Considering a yield loss of 5\%, the CPWC was 23 DAE and 7 DAE in the drip irrigation and micro sprinkler irrigation systems, respectively.
\end{abstract}

Keywords: Daucus carota L. Competition. Interference period. Drip. Micro sprinkler.

\section{INTERFERÊNCIA DE PLANTAS DANINHAS NA PRODUTIVIDADE DA CENOURA EM DOIS SISTEMAS DE IRRIGAÇÃO LOCALIZADA}

\begin{abstract}
RESUMO - A interferência de plantas daninhas representa um dos fatores de maior impacto na redução da produtividade na cultura da cenoura. O objetivo deste estudo foi determinar os períodos de interferência de plantas daninhas na cenoura em dois sistemas de irrigação localizada. O delineamento experimental utilizado foi o de blocos casualizados, com três repetições, no esquema de parcelas subdivididas. As parcelas foram constituídas dos dois sistemas de irrigação (gotejamento e microaspersão), e as subparcelas corresponderam à duração da convivência com as plantas daninhas, constituídos de períodos de controle (no limpo) ou convivência (no mato) das plantas daninhas com a cultura $(0,10,20,30,40,50$ e 120 dias após a emergência (DAE)). O início e o fim do período crítico de prevenção a interferência (PCPI), com base em uma perda de produtividade de 2,5, 5 e $10 \%$ de cenoura comercializável, foi determinado pelo ajuste do modelo Sigmoide aos dados de produção relativa. A presença da comunidade de plantas daninhas durante todo o ciclo da cultura pode acarretar perdas de até $98 \%$ na produtividade. O PCPI variou em 16 dias entre os sistemas de irrigação utilizados. O cultivo da cenoura com e sem competição, sob o sistema de irrigação por microaspersão apresentou maior produtividade em comparação ao cultivo no sistema de gotejamento. No sistema de irrigação por gotejamento o PCPI foi de 23 DAE e no sistema de irrigação por microaspersão foi de 7 DAE, considerando perdas de produtividade de $5 \%$.
\end{abstract}

Palavras-chave: Daucus carota L. Competição. Período de interferência. Gotejamento. Microaspersão.

\footnotetext{
${ }^{*}$ Corresponding author

${ }^{1}$ Received for publication in $11 / 17 / 2020$; accepted in $01 / 25 / 2021$

Paper extracted from the Agronomy Course Conclusion Work by the first author.

${ }^{2}$ Department of Agronomic and Forest Sciences, Universidade Federal Rural do Semi-Árido, Mossoró, RN, Brazil; laisttorquato@gmail.com - ORCID: 0000-0001-6726-6733, hamurabi_a_@hotmail.com - ORCID: 0000-0002-4548-9108, matheus_mafs10@hotmail.com - ORCID: 0000-0002-5424-6028, talianeteofilo23@gmail.com - ORCID: 0000-0003-3927-9371, vander@ufersa.edu.br - ORCID: 0000-0001-5682-5341, daniel.valadao@ufersa.edu.br - ORCID: 0000-0003-0644-2849.
} 


\section{INTRODUCTION}

The carrot (Daucus carota L.) is one of the most valuable vegetables in the tuberous root group. Worldwide carrot consumption is approximately 5.3 $\mathrm{kg}$ per person per year (FAOSTAT, 2017). The carrot has a pleasant taste and is rich in phenolic compounds, carotenoids, vitamins, minerals, and dietary fiber (HIRANVARACHAT; DEVAHASTIN, 2014). In Brazil, carrots have great relevance for the olive sector, occupying the fifth position among the vegetable producers with greater participation in the country's production (CARVALHO; SILVA 2017).

Irrigation in carrot cultivation increases productivity and improves the quality of harvested roots; however, both deficit and excess water and improper management can affect root development (LIMA JUNIOR et al., 2014). The Mossoró region, Rio Grande do Norte, Brazil, is characterized by a semi-arid climate, where limited water resources are highly exploited. In this region, vegetables are grown following the method of localized irrigation, using drip and micro sprinkler irrigation systems, which allows harvesting in the dry seasons (BEZERRA NETO et al., 2019).

Although irrigation contributes to improving the productivity of agricultural crops, weed interference is another important factor that limits crop production. In addition, competition between weeds and the crop can promote significant changes in the physiology of the cultivated plant, compromising its growth, productivity, and the quality of the harvested product (SARDANA et al., 2017).

The critical period of weed interference prevention (CPWC) is the time interval in which the crop needs to be maintained free of weeds to prevent loss in productivity (PITELLI, 1987). The period before interference (PPI) is the maximum amount of time after emergence that a crop can live with weeds without affecting its productivity. The total period of interference prevention (TPIP) is one wherein, from the moment of emergence, weeds must be controlled to avoid reduced productivity (KORRES; NORSWORTHY, 2015). Therefore, knowledge of the CPWP can be valuable in making decisions regarding the need for and time of weed control (LINS et al., 2019).
Carrots have low competitiveness with weeds owing to their slow emergence and growth at the beginning of the growing cycle. Swanton et al. (2008), while establishing a critical weed-free period in carrots, reported a loss of $92 \%$ to $100 \%$ in productivity when the weeds were left uncontrolled; mainly weed species from the Poaceae family and Digitaria. However, owing to variations in climatic conditions and composition of the weed community, the results of studies conducted in different environments or in different cultures may not apply to other systems (FREITAS et al., 2009; BRIMDEFOREST et al., 2017; FREITAS SOUZA et al. 2020a; MONTEIRO et al., 2021). Therefore, critical periods of weed competition and differences in composition between the weed community and the effects of competition on carrot production in different irrigation systems are not known.

The objectives of this study were to determine the periods of interference and the composition of the weed community in carrots under the drip and micro sprinkler irrigation systems and to quantify differences in productivity between the irrigation systems, both in the presence and absence of weeds.

\section{MATERIAL AND METHODS}

\section{Experiment location and area preparation}

The experiment was conducted at the experimental farm Rafael Fernandes of the Universidade Federal Rural do Semi-Árido, Mossoró, Rio Grande do Norte located at 5 $11^{\prime} 15^{\prime \prime} \mathrm{S}$, $37^{\circ} 20^{\prime} 39^{\prime \prime} \mathrm{W}$ and an altitude of $18 \mathrm{~m}$, between the months of July and November 2018. The climate of the region, according to the Köppen classification, is BSwh', dry and warm, with two climatic seasons: a dry one, which usually extends from June to January, and a rainy one, from February to May (CARMO FILHO; ESPÍNOLA SOBRINHO; MAIA NETO, 1991).

Soil preparation was performed by the conventional system, with plowing, harrowing, and formation of the beds with a rotary hoe. Chemical analysis of the soil was performed to determine planting fertilization (Table 1). Considering the recommendation of Cavalcanti (2008), $220 \mathrm{~kg} \mathrm{ha}^{-1}$ of $\mathrm{P}_{2} \mathrm{O}_{5}$ was applied during planting.

Table 1. Chemical properties of the $0-20 \mathrm{~cm}$ layer of soil in the experiment area.

\begin{tabular}{|c|c|c|c|c|c|c|c|c|c|c|c|c|}
\hline & $\mathrm{pH}$ & $\mathrm{P}$ & $\mathrm{K}$ & $\mathrm{Na}^{+}$ & \multirow[t]{2}{*}{$\mathrm{Ca}^{+2}$} & \multirow[t]{2}{*}{$\mathrm{Mg}^{+2}$} & $\mathrm{Al}^{+3}$ & $\mathrm{H}+\mathrm{Al}$ & \multirow[t]{2}{*}{ SB } & \multirow[t]{2}{*}{ CTC } & $\mathrm{V}$ & $\mathrm{M}$ \\
\hline & $\left(\mathrm{H}_{2} \mathrm{O}\right)$ & \multicolumn{3}{|c|}{$\left(\mathrm{mg} \mathrm{dm}^{-3}\right)$} & & & \multicolumn{2}{|c|}{$\left(\mathrm{cmol}_{\mathrm{c}} \mathrm{dm}^{-3}\right)$} & & & \multicolumn{2}{|c|}{$\%$} \\
\hline Soil & 5.90 & 6.3 & 50.3 & 5.8 & 1.10 & 0.6 & 0.20 & 2.31 & 1.85 & 4.16 & 45 & 10 \\
\hline
\end{tabular}

Potential acidity $(\mathrm{H}+\mathrm{Al})$; sum of bases (SB); cation exchange capacity (CTC); base saturation (V); saturation by aluminum (m). 


\section{Cultivation practices}

The carrot cultivar used for the experiment was 'Suprema', sown manually, with four seeds deposited per planting hole, in six rows. The spacing used was $0.15 \mathrm{~m}$ between lines and $0.08 \mathrm{~m}$ between plants. At 15 days after emergence (DAE), the crop was thinned, leaving only one plant per hole. As cover fertilization, $40 \mathrm{~kg} \mathrm{ha}^{-1}$ of $\mathrm{N}, 60 \mathrm{~kg} \mathrm{ha}^{-1}$ of $\mathrm{P}_{2} \mathrm{O}_{5}$, and $30 \mathrm{~kg} \mathrm{ha}^{-1}$ of $\mathrm{K}_{2} \mathrm{O}$ were applied, in the form of urea, simple superphosphate, and potassium chloride, respectively. Mechanical weeding (manual pulling) was performed at different time points as shown in Table 2. No herbicides were used during the experiment.

Table 2. Weed control and coexistence treatments and weed removal frequencies.

\begin{tabular}{cccc}
\hline Treatments & Weed interference period & Number of fields & Duration of living with weeds \\
\hline & (DAE) & & (Days) \\
1 & Weed-free period & 6 & 110 \\
2 & 120 days (Without competition) & 100 \\
3 & WFP until 10 days & 2 & 90 \\
4 & WFP until 20 days & 3 & 80 \\
5 & WFP until 30 days & 4 & 70 \\
6 & WFP until 40 days & 5 & 120 \\
1 & WFP until 50 days & & 10 \\
2 & Weeds period & 0 & 20 \\
4 & 120 days (With competition) & 5 & 30 \\
6 & WP until 10 days & 4 & 3 \\
\end{tabular}

Crop free from weed interference (WFP); Culture in coexistence with weeds (WP); Days after emergency (DAE).

\section{Experimental irrigation}

In the drip system, tapes were spaced $0.20 \mathrm{~m}$ between lines with $0.30 \mathrm{~m}$ between drippers. The micro sprinklers were spaced $1.0 \mathrm{~m} \times 1.0 \mathrm{~m}$ apart. The flow rate of the dripper was $1.5 \mathrm{~L} \mathrm{~h}^{-1}$, and that of the micro sprinklers was $54 \mathrm{~L} \mathrm{~h}^{-1}$.

First, a composite soil sampling of the entire experimental area was performed. The current soil moisture was calculated by the difference between the weight of the soil before and after kiln-drying for $12 \mathrm{~h}\left( \pm 105^{\circ} \mathrm{C}\right)$ (DOBRIYAL et al., 2012). The field capacity of the soil was estimated by the difference between the weight of the previously kiln-dried soil and the weight of the soil $72 \mathrm{~h}$ after being soaked with water. The conversion to the volume of water needed to raise the area's humidity to $80 \%$ of the field capacity was performed based on the approximate soil density of $1.4 \mathrm{~kg} \mathrm{dm}^{-3}$.

The irrigations during the carrot cycle were performed by calculating the specific blade sizes for each irrigation system (drip or micro sprinkler). The amount of water applied was estimated considering the calculated daily evapotranspiration in the region (ETo) and the coefficient (Kc) for carrot culture (ALLEN et al., 1998). The ETo calculation was performed using the equation proposed by Hargreaves and Samani (1985). The total water requirement for 2018 was calculated as $688 \mathrm{~mm}$ during the 120 days of carrot cultivation.

In the micro sprinkler system, the blade was applied daily (1-day watering shift) for the time necessary to supplement the amount of water required according to the ETc of the previous day. The time was calculated according to the spacing of the micro sprinklers, the flow rate of each micro sprinkler, and the efficiency of the system in providing the desired amount of water. For micro sprinkling, we consider an efficiency value of $80 \%$ (KOUMANOV et al., 1997).

The slides applied in the drip were calculated based on the values determined for the micro sprinkler. However, to highlight the differences between the irrigation systems and how they can affect the weed community in the area, the amount of water applied in the drip was $50 \%$ less than that with the micro sprinkler. This smaller amount of water was supplied daily (similar irrigation between drip and micro sprinkler), based on the spacing of the drippers and tapes, flow of the drippers, and efficiency of the drip system. Drip efficiency was set at 95\% (CAMP, 1998).

\section{Experimental design and treatments}

The experimental design used was that of randomized blocks, with three replications, using the split plot scheme. The plots consisted of the two 
irrigation systems (drip and micro sprinkler), and the subplots, divided into two groups, corresponded to the duration of weed coexistence in the treatments, control periods (in the clean) or coexistence (in the bush) of weeds with the crop (Table 2).

Each treatment in the subplots consisted of six lines $3.0 \mathrm{~m}$ in length. The usable area corresponded to the four central lines, with one line from each end of the plot discarded and used as borders.

At the end of each coexistence period, and at the time of the carrot harvest (120 days after sowing), weeds were collected from the infesting community using the sample square method. In the useful area of each plot, two samples were collected, through the random launching of a hollow square of $0.25 \times 0.25 \mathrm{~m}\left(0.0625 \mathrm{~m}^{2}\right)$. The aerial parts of the weeds were collected and separated by species for determining the number of individuals. Subsequently, the dry matter of the aerial part of the weeds was obtained by drying in an oven with forced air circulation at $65{ }^{\circ} \mathrm{C}$, until reaching a constant mass. Therefore, for phytosociological evaluation, weed density and dry matter were considered. Carrot productivity was evaluated after harvest, using the number and weight of the roots.

\section{Statistical analysis}

All data were subjected to the Shapiro-Wilk residual normality test (SHAPIRO; WILK, 1965). To test for homoscedasticity, the Bartlett's test (BARTLETT, 1951) was performed. The frequency and amount of dry matter of weed were assessed descriptively between treatments over the 120 days of carrot cultivation. To define the periods of interference in the different treatments, three sigmoidal models (Equation (1), Equation (2), and Equation (3)) were tested. The corrected Akaike information criterion (AICc), root mean square error (RMSE), and coefficient of determination $\left(R^{2}\right)$ were calculated to determine the model that best fitted the data. The values of PPI, CPWC, and TPIP were compared descriptively. The number of noncommercial roots at different time points and under different irrigation systems were subjected to analysis of variance using the $\mathrm{F}$ test.

Sigmoidal 4 parameters:

$$
y=y 0+\frac{a-y 0}{1+e^{-\left(\frac{x-x 0}{b}\right)}}
$$

Logistic sigmoidal:

$$
y=y 0+\frac{a-y 0}{1+\left(\frac{x}{x 0}\right)^{b}}
$$

Sigmoidal Gompertz:

$$
y=y 0+(a-y 0) e^{-e^{-\left(\frac{x-x 0}{b}\right)}}
$$

Mean squared error (4):

$$
R M S E=\sum_{i=1}^{N} \frac{(\text { estimated }- \text { observed })^{2}}{\text { Number of observations }}
$$

where, $y 0=$ inferior limit, $a=$ upper limit, $x 0=$ inflection point of the model, and $b=$ slope of the model.

When significant $(p \leq 0.05)$, the means were compared using Tukey's test. Productivity losses of $2.5 \%, 5.0 \%$, and $10 \%$ were established to determine the CPWP. The regression analysis and the preparation of graphs was performed using SigmaPlot ${ }^{\circledR}$ version 12.0.

\section{RESULTS AND DISCUSSION}

\section{Weed density and dry matter}

Under both irrigation systems, weed density (plants $\mathrm{m}^{-2}$ ) was reduced at $120 \mathrm{DAE}$ of the carrot crop (Figure 1). This reduction was close to $75 \%$ for the drip system (Figure 1A), and $92 \%$ for the micro sprinkler system (Figure 1B). The number of weed species also decreased over time in the carrot cultivation in the two irrigation systems (Figure 1).

The number of plants that emerged was high owing to the high availability of resources, mainly water, light, and nutrients. However, as plants grow, there is an increase in intra and interspecific competition, reducing the availability of resources, leaving only the species with the highest initial growth rate, and those with seeds of greater vigor or absence of dormancy (PAMPLONA et al., 2020). In the initial periods of coexistence of an infesting community with agricultural crops, there is a high density of infestation, whereas in the final periods there is a reduction in density, as was observed in this study. According to Bachega et al. (2013), weed species, especially those that germinate and emerge at the beginning of a crop cycle, intensify intra and interspecific competition and the taller and more developed plants become dominant and the smaller and less developed plants are suppressed or die. A study evaluating the CPWC in onion cultivated by drip and micro sprinkling during three agricultural seasons reported a similar behavior in relation to the density of individuals throughout the growing cycle, with an average reduction of $70 \%$ (FREITAS SOUZA et al. 2020a). 

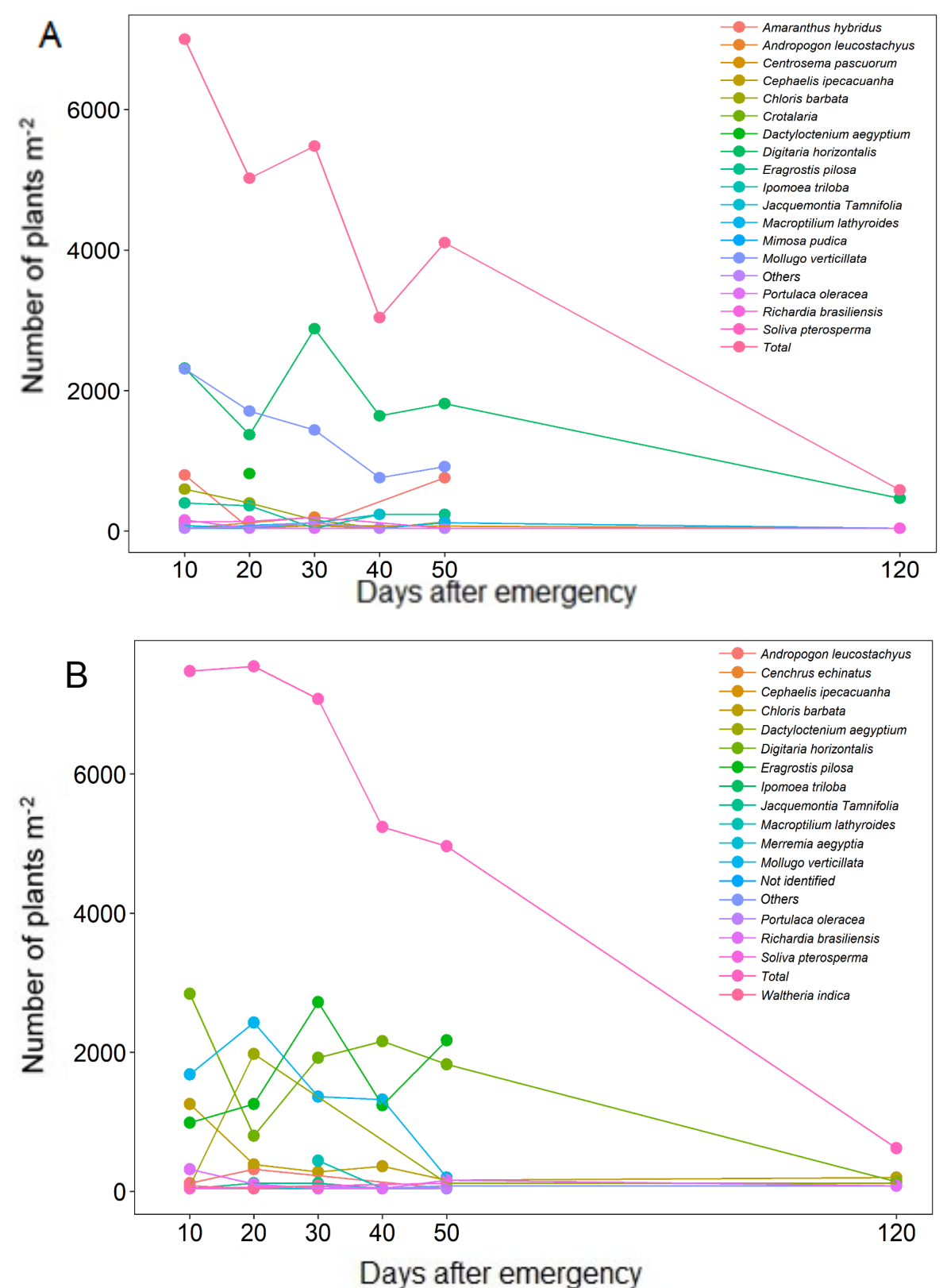

Figure 1. Density of weeds (plants $\mathrm{m}^{-2}$ ) identified in carrots grown in a drip system (A) and micro sprinkler (B) at 10, 20, $30,40,50$, and 120 (DAE).

In this study, Digitaria horizontalis Willd. showed a density of 1500 plants $\mathrm{m}^{-2}$ in relation to that of the other species in the drip system at 120 DAE (Figure 1A). The species Mollugo verticillata L. and Amaranthus hybridus L. had a density of 1500 plants $\mathrm{m}^{-2}$ up to 50 DAE (Figure 1A). However, at $120 \mathrm{DAE}$, these species were absent (Figure 1A). In the micro sprinkler system, the species with the highest density at 120 DAE in relation to the others was Chloris barbata L., with 1500 plants $\mathrm{m}^{-2}$ (Figure 1B). At 50 DAE, $M$. verticillata L. and Richardia brasiliensis Gomes. showed a density of 2000 plants $\mathrm{m}^{-2}$. However, these species were not observed at 120 DAE (Figure 1B).

In both the irrigation systems, there was a decline in weed density after 50 DAE (Figure 1). In the drip irrigation system, D. horizontalis Willd., from the Poaceae family, showed the highest density of plants (Figure 1A). This species has erect growth and is highly competitive for light, in addition to having good germinative potential and high efficiency in water use (GEALY, 2015; FAHEY; ANGELINI; FLORY, 2018). These characteristics make $D$. horizontalis Willd. more competitive than the other weeds present; therefore, in the drip irrigation system it stood out and dominated the area until 120 DAE. M. verticillata L. is a species of the Molluginaceae family with a low creeping habit and was only observed up to $50 \mathrm{DAE}$ as it was shaded by the other weeds and by the carrot crop. The species A. hybridus L., from the Amaranthaceae family, showed a high density of 1500 plants $\mathrm{m}^{-2}$ up to 50 DAE; however, owing to the intense competition with other plants for environmental resources, this 
species was not observed in the drip irrigation system (Figure 1A).

In the micro sprinkler irrigation system, $C$. barbata L. and $D$. horizontalis Willd. from the Poaceae family showed a higher density at 120 DAE than that of the other species (Figure 1B). These weeds are common in diverse agricultural areas because they have ruderal characteristics and unusual competitive aggressiveness that makes them predominate in relation to other species and directly affect crop productivity (FREITAS SOUZA et al., 2020b). At 50 DAE, the species observed with the highest density were Eragrostis pilosa L. and $D$. horizontalis Willd. (Figure 1B) both from the Poaceae family. These species show $\mathrm{C} 4$ metabolism and under conditions of excessive light, their photosynthetic rates are high, which makes them more efficient and competitive than $\mathrm{C} 3$ plants (FERNANDO et al., 2016).

In the drip irrigation system, the species with the highest amount of dry matter was $D$. horizontalis Willd., with $6.032 \mathrm{~g} \mathrm{~m}^{-2}$ at 120 DAE (Figure 2A). At 120 DAE, it was also observed that Centrosema pascuorum Mart. ex Benth. and Macroptilium lathyroides (L.) Urb. did not make substantial contributions in terms of the amount of dry matter in the system (Figure 2A). In the micro sprinkler system, C. barbata L., with $2.112 \mathrm{~g} \mathrm{~m}^{-2}$, presented the highest amount of dry matter (Figure 2B). However, species such as $D$. horizontalis Willd., $R$. brasiliensis Gomes, and Dactyloctenium aegyptium (L.) Willd. also presented high levels of dry matter at 120 DAE of the crop (Figure 2B).
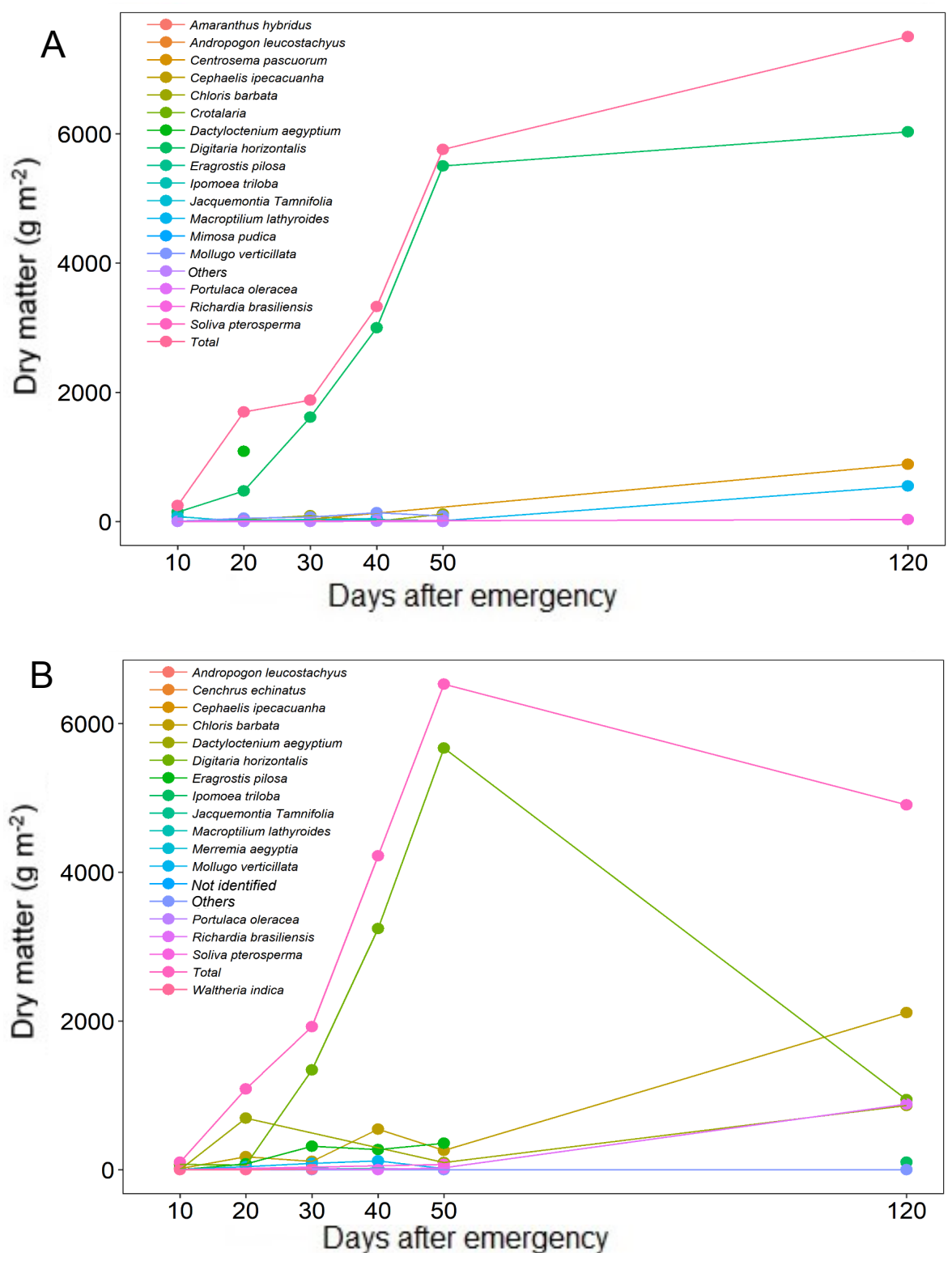

Figure 2. Weed dry matter $\left(\mathrm{g} \mathrm{m}^{-2}\right)$ identified in carrots grown in a drip system (A) and micro sprinkler system (B) at 10 , $20,30,40,50$, and $120 \mathrm{DAE}$. 
The total accumulation of dry matter can be considered a more reliable indicator than the weed population when it comes to the degree of interference imposed on a crop (BRIGHENTI et al., 2004). However, in both irrigation systems, it can be noted that the plants of the Poaceae family were highly competitive and prevailed in the cultivation area until 120 DAE of the crop, and the same was observed for the plant population density. The other weed species did not show significant dry matter accumulation after 50 DAE (Figure 2). In addition, the dry matter of weeds in the micro sprinkler system decreased after 50 DAE (Figure 2A). This is a result of the shading by larger plants, which showed rapid initial development owing to the high luminosity rate, thus helping to control smaller plants, and the more intense competition for environmental resources. In addition, the microclimate created by the water droplets of the irrigation system maintained crop moisture, and coupled with high temperatures, also favored the decomposition of suppressed weeds. Silva et al. (2015), evaluating weed density on soybean production components, also observed a decrease in infestation at 125 DAE, the end of the evaluation period. Comparing the two irrigation systems used for carrot cultivation, the system with the highest amount of dry matter was the drip system, resulting in 50\% more dry matter of weeds than that with the micro sprinkler system.

\section{Carrot productivity and periods of weed control and coexistence}

Three sigmoidal models were tested to estimate the relative yield of the carrot crop based on the periods with and without competition between the crop and the weeds (Table 3). For the period without competition, an $\mathrm{RMSE}=0.13$ and $R^{2}=0.98$ was obtained for the 4-parameter sigmoidal model tested, and an RMSE $=0.14$ and $R^{2}=0.99$ for the period of competition (Table 3 ). The AICc value for this model was 142.54 (Table 3 ). For the sigmoidal Gompertz model, an RMSE $=0.36$ and 0.35 and $R^{2}=$ 0.96 and 0.97 were obtained for the periods without and with competition, respectively (Table 3). The AICc value for the sigmoidal Gompertz model was 151.39 (Table 3). The third model tested was the sigmoidal logistic model, in which an RMSE $=0.49$ and 0.44 and $R^{2}=0.44$ and 0.97 were obtained for the period without and with competition, respectively (Table 3). The AICc value for this model was 158.31 (Table 3).

Table 3. Parameters ( $y 0, a, x 0$ and $b$ ), root of the mean square of the error (RQME), coefficient of determination $\left(R^{2}\right)$, and Akaike test value (AICc) of the adjusted models Sigmoidal 4 parameters, Sigmoidal Gompertz and Sigmoidal logistic used to estimate the relative production of carrots, without and with competition with weeds, in the drip irrigation system.

\begin{tabular}{|c|c|c|c|c|c|c|c|}
\hline & \multicolumn{4}{|c|}{ Sigmoidal 4 parameters } & \multirow{3}{*}{ RQME } & \multirow{3}{*}{$R^{2}$} & \multirow{3}{*}{$\mathrm{AICc}$} \\
\hline & \multicolumn{4}{|c|}{ Parameters } & & & \\
\hline & $y 0$ & $A$ & $x 0$ & $b$ & & & \\
\hline Weed-free & 2.07 & 100.18 & 21.12 & -2.56 & 0.13 & 0.98 & \multirow{2}{*}{$142.54 *$} \\
\hline \multirow[t]{4}{*}{ Weedy } & 0.17 & 112.51 & 23.14 & 11.23 & 0.14 & 0.99 & \\
\hline & \multicolumn{4}{|c|}{ Sigmoidal Gompertz } & & & \\
\hline & \multicolumn{4}{|c|}{ Parameters } & \multirow{2}{*}{ RQME } & \multirow{2}{*}{$R^{2}$} & \multirow{2}{*}{$\mathrm{AICc}$} \\
\hline & $y 0$ & $A$ & $x 0$ & $b$ & & & \\
\hline Weed-free & 2.78 & 99.76 & 19.87 & -2.49 & 0.36 & 0.96 & \multirow{2}{*}{151.39} \\
\hline \multirow[t]{4}{*}{ Weedy } & 0.83 & 136.54 & 26.14 & 22.17 & 0.35 & 0.97 & \\
\hline & \multicolumn{4}{|c|}{ Logistic sigmoidal } & & & \\
\hline & \multicolumn{4}{|c|}{ Parameters } & \multirow{2}{*}{ RQME } & \multirow{2}{*}{$R^{2}$} & \multirow{2}{*}{$\mathrm{AICc}$} \\
\hline & $y 0$ & $A$ & $x 0$ & $b$ & & & \\
\hline Weed-free & 2.76 & 99.81 & 20.85 & -10.98 & 0.49 & 0.95 & \multirow{2}{*}{158.31} \\
\hline Weedy & 2.98 & 97.67 & 25.26 & 2.58 & 0.44 & 0.97 & \\
\hline
\end{tabular}

*Indicates model chosen according to Akaike criteria for selection of aligned models.

** $y 0$ : lower limit, $x 0$ : inflection point of the model, $a$ : upper limit, $b$ : slope of the model.

The model that adjusted the most according to the Akaike test criteria was the sigmoidal model with four parameters and was chosen because it presented lower RMSE values than those with the other tests, meaning that the adjusted model had a smaller error. In addition, the values obtained for $R^{2}$ for the 
sigmoidal model with four parameters were the closest to 1 and the AICc value was the lowest in relation to that of the other tests. A study conducted with three maize cultivars to characterize the influence of the duration of weed interference on relative productivity, using four parameters and opting for the sigmoidal logistic model, found that the duration of weed competition or competition-free culture influenced the relative productivity of corn, regardless of the corn cultivar (TURSUN et al., 2016a).

Carrot productivity in the micro sprinkler irrigation system in the competition and noncompetition periods was also evaluated using the three sigmoidal models (Table 4). With the sigmoidal model, RMSE $=0.23$ and 0.21 was obtained for the period without and with competition, respectively, and $R^{2}=0.99$ was obtained in both cases (Table 4). The AICc value for the sigmoidal model was 131.61 (Table 4). For the sigmoidal Gompertz model, the RMSE values in the period without and with competition were 0.56 and 0.55, respectively, with $R^{2}=0.98$ and 0.99 , respectively (Table 4). The AICc value for the sigmoidal Gompertz model was 132.04 (Table 4). The sigmoidal logistic model in the period without competition presented RMSE values of 0.69 and $R^{2}$ of 0.98 (Table 4), whereas with competition, the values were $\mathrm{RMSE}=0.91$ and $R^{2}=0.98$ (Table 4) The AICc result for this model was 132.83 (Table 4).

Table 4. Estimated parameters ( $y 0, a, x 0$ and $b$ ), root of the mean square of the error (RQME), coefficient of determination $\left(R^{2}\right)$, and Akaike test value (AICc) of the adjusted models Sigmoidal 4 parameters, Sigmoidal Gompertz and Sigmoidal logistic used for estimate the relative production of the carrot, without and with competition with weeds, in the microsprinkler system.

\begin{tabular}{|c|c|c|c|c|c|c|c|}
\hline & \multicolumn{4}{|c|}{ Sigmoidal 4 parameters } & \multirow{3}{*}{ RQME } & \multirow{3}{*}{$R^{2}$} & \multirow{3}{*}{$\mathrm{AICc}$} \\
\hline & \multicolumn{4}{|c|}{ Parameters } & & & \\
\hline & $y 0$ & $a$ & $x 0$ & $b$ & & & \\
\hline Weed-free & 0.78 & 101.14 & 19.26 & -2.23 & 0.23 & 0.99 & $131.61 *$ \\
\hline \multirow[t]{4}{*}{ Weedy } & 0.6 & 99.72 & 35.74 & 4.65 & 0.21 & 0.99 & \\
\hline & \multicolumn{4}{|c|}{ Sigmoidal Gompertz } & & & \\
\hline & \multicolumn{4}{|c|}{ Parameters } & ROMF & $R^{2}$ & $\Delta \mathrm{ICc}$ \\
\hline & $y 0$ & $a$ & $x 0$ & $b$ & & & \\
\hline Weed-free & 0 & 101.51 & 18.12 & -3.13 & 0.56 & 0.98 & 132.04 \\
\hline \multirow[t]{4}{*}{ Weedy } & 2.91 & 100.45 & 38.21 & 6.18 & 0.55 & 0.99 & \\
\hline & \multicolumn{4}{|c|}{ Logistic sigmoidal } & & & \\
\hline & \multicolumn{4}{|c|}{ Parameters } & POMГ & $D^{2}$ & 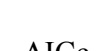 \\
\hline & $y 0$ & $a$ & $x 0$ & $b$ & सिए & & \\
\hline Weed-free & 0.35 & 98.8 & 35.58 & -7.77 & 0.69 & 0.98 & 132.83 \\
\hline Weedy & 0.12 & 101 & 19.31 & 9.06 & 0.91 & 0.98 & \\
\hline
\end{tabular}

*Indicates model chosen according to Akaike criteria for selection of aligned models.

** $y 0$ : lower limit, $x 0$ : inflection point of the model, $a$ : upper limit, $b$ : slope of the model.

The model that fitted the most according to the Akaike criteria test was the sigmoidal four parameters model; this model also presented $R^{2}$ values closer to 1 and the AICc value was the lowest in relation to the other tests. For both irrigation systems, the sigmoidal model was the one that showed the best fit to estimate the relative production of the carrot crop with and without competition with the weeds. Tursun et al. (2016b), conducting studies to characterize the influence of the duration of weed interference on relative cotton productivity, observed that the logistic sigmoidal model showed a better fit, with the crop being affected by the weed interference duration or by the weed-free period, and that increasing periods of weed interference caused a significant reduction in cotton productivity.

As shown in Figure 3, the yield curves were adjusted using the chosen sigmoid model, according to the periods with and without coexistence of the crop with weeds for both irrigation systems. There was an interaction between the irrigation systems and the beginning and end of the CPWC; therefore, the periods of interference were analyzed separately for each irrigation system. The relative productivity of the carrot crop was affected in both irrigation 
systems used. However, it was observed that in the micro sprinkler irrigation system, the beginning and end of the CPWC was, on average, 16 days shorter than that in the drip irrigation system which presented a longer CPWC of approximately 23 days, considering a productivity loss of $5 \%$ (Figure 3 ). This result correlated significantly with the weed density and amount of dry matter, i.e., the amount and the composition of the weed community present in the study area was greater in the drip irrigation system than in the micro sprinkler irrigation system, presenting positive competition and thereby increasing the CPWC in the drip irrigation system.
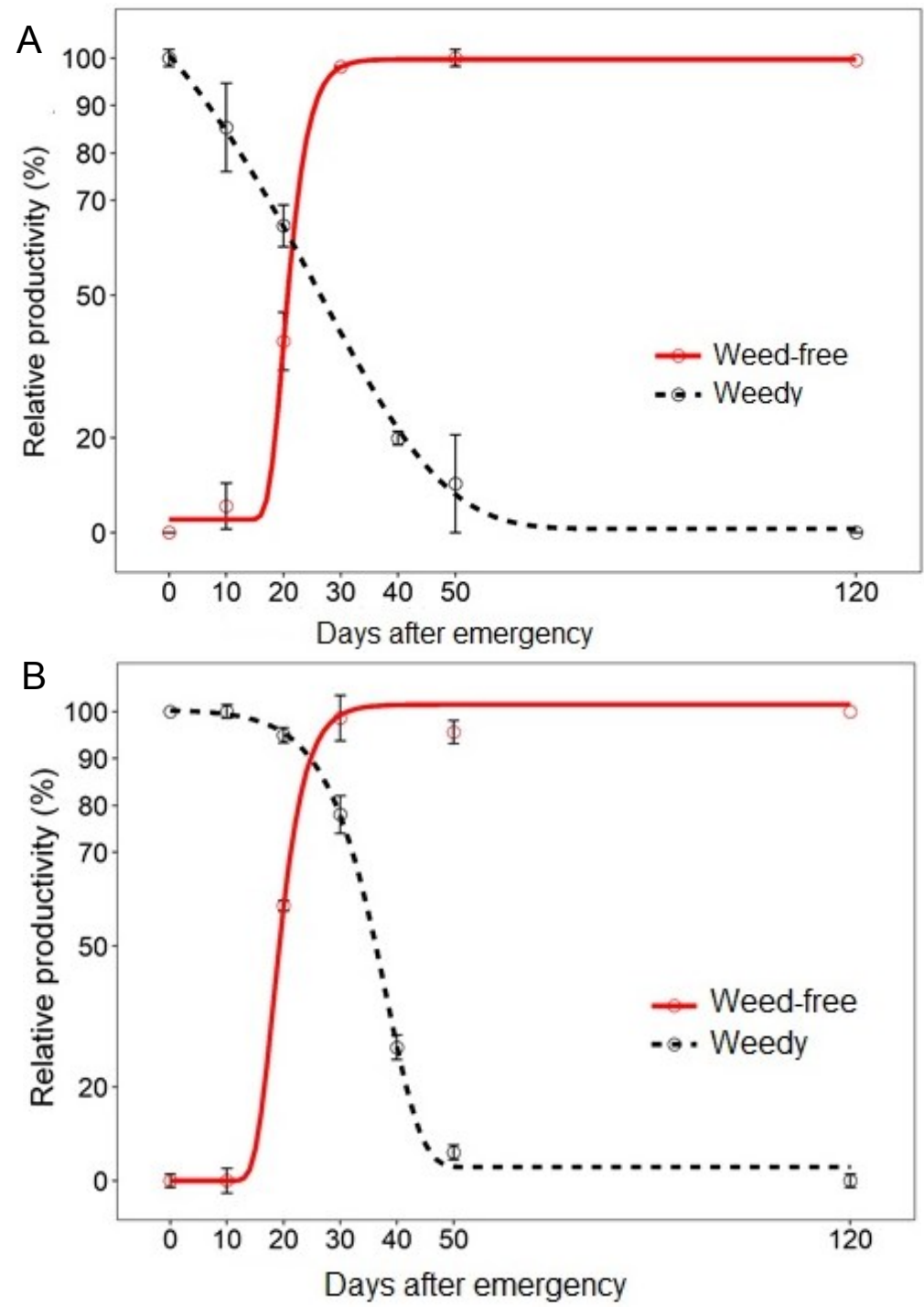

Figure 3. Sigmoide model chosen to describe the relative productivity of the carrot (\%), without and with competition with weeds, in a drip system (A) and micro sprinkler (B) for 120 days after emergence.

The presence of weeds during the entire cycle of carrot cultivation caused losses of up to $98 \%$ in productivity. This reduction in productivity was caused by prolonged delays in the removal of weeds in the two irrigation systems. However, the productivity of the carrot roots increased with the increasing duration of the weed-free period in the two irrigation systems (Figure 3). A significant decrease in the yield of carrot roots can be explained mainly by the interference of $D$. horizontalis Willd. in both irrigation systems. During the period of 10 to 40 DAE, this weed suppressed the carrot plants, covered the soil surface, and dominated the entire growing area. As a plant with a $\mathrm{C} 4$ mechanism, $D$. Horizontalis Willd. is very efficient in the use of resources such as water, nutrients, and especially light, and therefore, it presents accelerated growth, resulting in the reduction in the photosynthetic rate of the cultivated species, affecting its growth and the rate of biomass accumulation (LINS et al., 2019; FREITAS SOUZA et al., 2020a; FREITAS SOUZA et al., 2020b).

All data on acceptable losses were analyzed separately because there was an interaction between 
weed density and irrigation systems (Table 5). Weed interference periods varied between irrigation systems (Figure 1). Considering an acceptable loss of $2.5 \%$ for the drip irrigation system, the PPI was established at 3 DAE (Table 5). The CPWC was established in 26 days, obtaining a TPIP of 29 DAE
(Table 5). However, considering the same acceptable loss for the micro sprinkler system, the PPI was established at 17 DAE (Table 5). The CPWC was established in 11 days, thus obtaining a TPIP of 28 DAE.

Table 5. Period prior to interference (PPI), Critical period of weed control (CPWC) and Total period of interference prevention (TPIP) for weed control in two irrigation systems (drip and micro sprinkler) in the carrot crop, considering an acceptable loss of $2.5,5$, and $10 \%$.

\begin{tabular}{|c|c|c|c|c|}
\hline \multirow{2}{*}{ Acceptable Loss of Productivity (\%) } & \multirow{2}{*}{ Irrigation system } & \multicolumn{3}{|c|}{ Weed Interference Periods } \\
\hline & & PPI* & CPWC & TPIP * \\
\hline \multirow{2}{*}{2.5} & Drip & 3 & 26 & 29 \\
\hline & Micro sprinkler & 17 & 11 & 28 \\
\hline \multirow{2}{*}{5} & Drip & 4 & 23 & 27 \\
\hline & Micro sprinkler & 20 & 7 & 27 \\
\hline \multirow{2}{*}{10} & Drip & 7 & 19 & 26 \\
\hline & Micro sprinkler & 25 & 0 & 25 \\
\hline
\end{tabular}

*Days after emergency (DAE).

When considering a loss of $5 \%$ for the drip system, the established PPI was $4 \mathrm{DAE}$, and the CPWC was 23 days, obtaining a TPIP of 27 DAE (Table 5). In the micro sprinkler system considering the acceptable loss of 5\%, the PPI established for the culture was $20 \mathrm{DAE}$, with a CPWC of 7 days and TPIP of 27 DAE (Table 5). Allowing an acceptable loss of $10 \%$, in the drip irrigation system, the established PAI was 7 DAE (Table 5). The CPWC was 19 days and the TPIP was established at 26 DAE (Table 5). For the micro sprinkler system, considering the same $10 \%$ loss, the PBI and TPIP established were $25 \mathrm{DAE}$ (Table 5), requiring only one weeding in the entire growing cycle.

In the present study, the CPWC varied in the carrot crops owing to the irrigation systems used. In the drip irrigation system, weed control must be started on the 4th DAE. In the micro sprinkler irrigation system, weed control must start at the 20th DAE and the period in which the crop must be kept free of weeds (CPWC) is 23 days considering a 5\% productivity loss when compared to the drip irrigation system, for which it was 7 days (Table 5).

The difference between the interference periods is related to the availability of water in the cultivation area. The greater competition for water in the crop line in the drip system may have caused a greater CPWC and greater losses in carrot productivity, as under this irrigation system, water is supplied close to the root zone of the plants; thus, competition for water and nutrients in the line is intensified, contributing to the rapid development of weeds and consequent shading, resulting in slower crop development. The wider distribution of water in the cultivation area with the micro sprinkler system makes water available both in the cultivation lines and between the lines and the movement of this water in the soil may have favored the faster growth and development of the carrots. The movement of water in the soil directly influences changes in soil temperature and the migration of nutrients, affecting crop growth and productivity (LI et al., 2017). Considering all levels of productivity losses, the competition of the carrot crop with weeds in the micro sprinkler system was lower than that in the drip irrigation system.

The high infestation of $D$. horizontalis Willd. at the beginning of crop development, may have been the factor that influenced competition among weeds the most during the carrot cultivation cycle in the drip irrigation system. As a C4 metabolism plant, this damaging species is better adapted to more intense temperature and light, presenting greater efficiency in the use of water (TAYLOR et al., 2011). Therefore, the lower availability of water in this system may have intensified competition for this resource, limiting the growth and development of the crop. In the micro sprinkler irrigation system owing to the greater availability and distribution of water, competition for this resource may have been less, and therefore, the later requirement for starting weed control.

The carrot crop is a high value-added vegetable and the period that the crop remains in competition with weeds may compromise the development of its roots, which are its main commercial part, resulting in reduced productivity. This emphasizes the importance of weed control 
during early development in the crop cycle (COLQUHOUN; RITTMEYER; HEIDER, 2017) and the weed-free critical period, as demonstrated in this study. Conducting further studies for a better understanding of the factors of carrot establishment and their relationship with weed control is essential for maintaining good productivity.

In both irrigation systems, the number of noncommercial roots increased with increasing DAE; the same occurred for the weight of non-commercial roots (Table 6). At $120 \mathrm{DAE}$, the number of noncommercial roots was 119 and 87 roots for the drip and micro sprinkler systems, respectively. In the micro sprinkler system, the number of noncommercial roots did not differ significantly between 40 to 120 DAE (Table 6). There was no significant difference between irrigation systems for the number and weight of roots in all control periods. In the micro sprinkler irrigation system, there was no difference in root weight in the period between 40 to 120 DAE. The root weight at $120 \mathrm{DAE}$ was $9.312 \mathrm{~kg}$ and $11.113 \mathrm{~kg}$ in the drip and micro sprinkler systems, respectively. Irrigation systems did not influence the number and weight of non-commercial roots (Table 6).

Table 6. Number of non-commercial roots and weight of non-commercial roots for drip irrigation and micro sprinkler systems in different growing periods of weed coexistence with carrots.

\begin{tabular}{|c|c|c|c|c|}
\hline \multirow{2}{*}{ DAE* } & \multicolumn{2}{|c|}{ Number of non-commercial roots } & \multicolumn{2}{|c|}{ Non-commercial root weight $(\mathrm{Kg})$} \\
\hline & Drip & Micro sprinkler & Drip & Micro sprinkler \\
\hline 10 & $1.2 \mathrm{Aa}$ & $7.33 \mathrm{aA}$ & $0.146 \mathrm{aA}$ & $0.104 \mathrm{aA}$ \\
\hline 20 & $17.66 \mathrm{aA}$ & $9.33 \mathrm{aA}$ & $1.69 \mathrm{bA}$ & $0.476 \mathrm{aA}$ \\
\hline 30 & $53.66 \mathrm{bA}$ & $38.33 \mathrm{aA}$ & $3.16 \mathrm{bA}$ & $3.206 \mathrm{bA}$ \\
\hline 40 & $61.33 \mathrm{bA}$ & $66.00 \mathrm{bA}$ & $5.758 \mathrm{cA}$ & $8.532 \mathrm{cA}$ \\
\hline 50 & $71.00 \mathrm{bA}$ & $71.33 \mathrm{bA}$ & $5.954 \mathrm{cA}$ & $8.706 \mathrm{cA}$ \\
\hline 120 & $118.33 \mathrm{cA}$ & $86.67 \mathrm{bA}$ & $9.312 \mathrm{dA}$ & $11.133 \mathrm{cA}$ \\
\hline
\end{tabular}

*Days after emergency (DAE).

*Equal lowercase letters indicate that the growing periods of weed coexistence with the carrot (DAE) were not significant, the same uppercase letters indicate that there were no significant differences between the irrigation systems, at the level of $5 \%$ probability by the Tukey test.

The increasing periods of weed coexistence contributed to the increase in the number of noncommercial roots, which may be a result of the intensification of the interference imposed by weeds throughout the crop cycle. Freitas et al. (2009) found that weed infestation interferes with the growth and development of the roots of the carrot, reducing the size and diameter of the roots. In addition, weed interference can also affect the quality of carrot roots, causing deformations and hindering their commercialization (MARTINS; MARCHI; COSTA, 2013).

\section{CONCLUSIONS}

The different irrigation systems influenced the CPWC. Considering a productivity loss of $5 \%$, in the drip irrigation system, the CPWC was 23 days and that in the micro sprinkler irrigation system was 7 days. In the drip irrigation system, weed control must be started at the 4th DAE, whereas it must be started at the 20th DAE in the micro sprinkler irrigation system. The population composition of weeds was greater at the beginning of the carrot development cycle, with a decrease in population density and the number of dominant species at the end of the crop cycle. The predominant species in the cultivation under drip irrigation system was Digitaria horizontalis L., whereas it was Chloris barbata L. and $D$. horizontalis $\mathrm{L}$ in the micro sprinkler irrigation system. The cultivation of carrots with and without competition, under the micro sprinkler irrigation system presents greater productivity than that with the cultivation in the drip system. The results of this study contribute to the development of an integrated weed management system to be followed by producers for the cultivation of carrots.

\section{REFERENCES}

ALLEN, R. G. et al. Crop evapotranspiration: guidelines for computing crop water requirements. In: FAO Irrigation and Drainage Paper No. 56. Rome: FAO, 1998. 300 p.

BACHEGA, L. P. S. et al. Períodos de interferência de plantas daninhas na cultura do quiabo. Planta 
Daninha, 28: 63-70, 2013.

BARTLETT, M. S. An inverse matrix adjustment arising in discriminant analysis. The Annals of Mathematical Statistics, 22: 107-111, 1951.

BEZERRA NETO, F. et al. Productive viability and profitability of carrot-cowpea intercropping using different amounts of Calotropisprocera.Revista Caatinga, 32: 62-71, 2019.

BRIGHENTI, A. M. et al. Períodos de interferência de plantas daninhas na cultura do girassol. Planta Daninha, 22: 51-257, 2004.

BRIM-DEFOREST, W. B. et al. Weed community dynamics and system productivity in alternative irrigation systems in California rice. Weed Science, 65: 177-188, 2017.

CAMP, C. R. Subsurface drip irrigation: a review. Transactions of the ASAE, 41: 1353, 1998.

CARMO FILHO, F.; ESPÍNOLA SOBRINHO, J.; MAIA NETO, J. M. Dados climatológicos de Mossoró: um município do semi-árido nordestino. Mossoró, RN: ESAM, 1991. 121 p.

CARVAlHO, A. D. F.; SILVA, G. O. Divergência genética entre genótipos de cenoura através de caracteres agronômicos. Revista Agroambiente, 11: 137-144, 2017.

CAVALCANTI, F. J. A. Fertilizer recommendations for the state of Pernambuco: $2^{\text {a }}$ aproximation. Recife, PE: IPA, 2008. 212 p.

COLQUHOUN, J. B.; RITTMEYER, R. A.; HEIDER, D. J. Tolerance and Suppression of Weeds Varies among Carrot Varieties. Weed Technology, 31: 897-902, 2017.

DOBRIYAL, P. et al. A review of the methods available for estimating soil moisture and its implications for water resource management. Journal of Hydrology, 458: 110-117, 2012.

FAHEY, C.; ANGELINI, C.; FLORY, S. L. Grass invasion and drought interact to alter the diversity and structure of native plant communities. Ecology, 99: 2692-2702, 2018.

FAOSTAT - Food and Agriculture Data. Produtividade da Cenoura. 2017. Disponível em: $<$ http://www.fao.org/faostat/en/\#data/QC $>$. Acesso em: 20 jan. 2021.

FERNANDO, N. et al. Glyphosate resistance of $\mathrm{C}_{3}$ and $\mathrm{C}_{4}$ weeds under rising atmospheric $\mathrm{CO}_{2}$. Frontiers in plant science, 7: 910, 2016.
FREITAS, F. C. L. et al. Períodos de interferência de plantas daninhas na cultura da cenoura em função do espaçamento entre fileiras. Planta Daninha, 27: 473 $-480,2009$.

FREITAS SOUZA, M. et al. Can irrigation systems alter the critical period for weed control in onion cropping? Crop Protection, 2020: 1-7, 2020a.

FREITAS SOUZA, M. et al. Soil water availability alter the weed community and its interference on onion crops. Scientiae Horticulturae, 272: 1-10, $2020 b$.

GEALY, D. R. Deep phosphorus fertiliser placement and reduced irrigation methods for rice (Oryza sativa L.) combine to knock-out competition from its nemesis, barnyard grass (Echinochloa crus-galli (L.) P. Beauv). Plant and Soil, 391: 427-431, 2015.

HARGREAVES, G. H.; SAMANI, Z. A. Reference crop evapotranspiration from temperature. Applied Engineering in Agriculture, 1: 96-99, 1985.

HIRANVARACHAT, B.; DEVAHASTIN, S Enhancement of microwave-assisted extraction via intermittent radiation: Extraction of carotenoids from carrot peels. Journal of Food Engineering, 126: 1726, 2014.

KOUMANOV, K. S. et al. Application efficiency of micro-sprinkler irrigation of almond trees.Agricultural Water Management, 34: 247263,1997

KORRES, N. E.; NORSWORTHY, J. K. Influence of a rye cover crop on the critical period for weed control in cotton. Weed Science, 63: 346-352, 2015.

LIMA JUNIOR, J. A. et al. Economic viability of a drip irrigation system on carrot crop. Journal of Agricultural and Environmental Sciences, 57: 15$21,2014$.

LI, X. et al. Spatial distribution of soil water, soil temperature, and plant roots in a dripirrigated intercropping field with plastic mulch. European Journal of Agronomy, 83: 47-56, 2017.

LINS, H. A. et al. Weed interference periods in sesame crop. Ciência e Agrotecnologia, 43: e000819, 2019

MARTINS, D.; MARCHI, S. R.; COSTA, N. V. Weed interference periods on potato crop in Botucatu region, Brazil. African Journal of Agricultural Research, 8: 2224-2231, 2013.

MONTEIRO, A. L. et al. A new alternative to determine weed control in agricultural systems based 
on artificial neural networks (ANNs). Field Crops

Research, 263: 108075, 2021.

PAMPLONA, J. P. et al. Seed germination of Bidens subalternans DC. exposed to different environmental factors. PLOS ONE, 15: e0233228, 2020.

PITELLI, R. A. Competição e controle de plantas daninhas em áreas agrícolas. IPEF, 4: 25-35, 1987.

SARDANA, V. et al. Role of competition in managing weeds: An introduction to the special issue. Crop Protection, 95: 1-7, 2017.

SHAPIRO, S. S.; WILK, M. B.An analysis of variance test for normality (complete samples). Biometrika, 52: 591-611, 1965.

SILVA, A. A. P. et al. Interference periods among weeds and soybean RR crops in the western center area of the brazilian state of Paraná. Planta Daninha, 33: 707-716, 2015.

SWANTON, C. J. et al. Integrated weed management: Knowledge-based weed managementsystems. Weed Science, 56: 168-172, 2008.

TAYLOR, S. H. et al. Drought limitation of photosynthesis differs between $\mathrm{C}_{3}$ and $\mathrm{C}_{4}$ grass species in a comparative experiment. Plant, Cell and Environment, 34: 65-75, 2011.

TURSUN, N. et al. The critical period for weed control in three corn (Zea mays L.) types. Crop Protection, 90: 59-65, 2016a.

TURSUN, N. et al. Row spacing impacts the critical period for weed control in cotton (Gossypium hirsutum). Phytoparasitica, 44: 139-149, 2016 b. 